\title{
Metabolism and ruminal parameters of Holstein $\times$ Gir heifers fed sugarcane and increasing levels of crude protein ${ }^{1}$
}

\section{Maria Fernanda Soares Queiroz ${ }^{2}$, Telma Teresinha Berchielli ${ }^{2 *}$, Ricardo Dias Signoretti ${ }^{3}$, Andressa Ferreira Ribeiro ${ }^{2}$, Juciléia Aparecida da Silva Morais ${ }^{2}$}

\author{
${ }^{1}$ Research financed by Fapesp. \\ 2 Faculdade de Ciências Agrárias e Veterinárias - UNESP, Campus de Jaboticabal. \\ ${ }^{3}$ APTA Regional Alta Mogiana, Colina - SP. \\ ${ }^{*}$ Researcher from CNPq, member of INCT-CA.
}

ABSTRACT - The objective of this study was to evaluate the effect of increasing levels of crude protein (CP) in the $\operatorname{diet}(13,15,19$ and $22 \mathrm{~g} / 100 \mathrm{~g}$ of dry matter, DM) on the metabolism and ruminal parameters of crossbred heifers fed forage sugarcane. Four crossbred Holstein $\times$ Gir heifers of average initial weight of $200 \mathrm{~kg}$ and average age of 14 months were used. The experimental design was in a $4 \times 4$ latin square. The intake values of DM, organic matter $(\mathrm{OM})$, neutral detergent fiber (NDF) and non-fibrous carbohydrates (NFC) were not affected by the protein contents of the diet. The apparent and ruminal digestibility of DM and $\mathrm{OM}$ were affected by the protein content of the diet. Greater total apparent digestibility coefficient of CP (0.749) was observed for the content of $22 \mathrm{~g} \mathrm{CP} / 100 \mathrm{~g} \mathrm{DM}$, whereas the ruminal digestibility of CP was not affected by treatments. The efficiency of microbial protein synthesis was not different between the CP contents of the diet. There was increasing linear effect of the $\mathrm{CP}$ content in the diet on the plasma concentration of urea. The rumen $\mathrm{pH}$ of the heifers was similar between treatments, with an average of 6.3. The concentration of rumen ammonia nitrogen was affected by the protein content of the diet, with the highest averages at 22 and $19 \mathrm{CP} / 100 \mathrm{~g} \mathrm{DM}(27.5$ and $31.6 \mathrm{mg} / \mathrm{dL})$; an average of $21.1 \mathrm{mg} / \mathrm{dL}$ in the diet with $15 \mathrm{~g} \mathrm{CP} / 100 \mathrm{~g} \mathrm{DM}$; and the lowest average observed in the diet containing $13 \mathrm{~g} \mathrm{CP} / 100 \mathrm{~g} \mathrm{DM}, 14.0 \mathrm{mg} / \mathrm{dL}$. It is recommended to use $13 \mathrm{~g} \mathrm{CP} / 100 \mathrm{~g} \mathrm{DM}$ in the diet for crossbred Holstein $\times$ Gir heifers in the post-weaning phase consuming diets based on sugarcane, because this level promotes increase in the digestibility of the diet and lower concentrations of plasma urea nitrogen and ammonia nitrogen, showing better animal metabolism, in addition to a possible decrease in the cost of the diet.

Key Words: digestibility, microbial synthesis, plasma urea, protein fractionation

\section{Introduction}

Replacement heifers are the basis of any system of dairy exploitation and, in Brazil, they have an important participation in the production cost. Herd breeding is possible when older cows are replaced by better fed, healthy and genetically superior animals; however, dairy replacement heifers require adequate amounts of protein in the diet which enable healthy growth (Hoffman et al., 2001) for them to start reproduction between the 15th and the 18th months of age, in addition to maintaining pregnancy.

Most of the forages can be supplied to heifers, and a big percentage of farmers utilize pastures during all the year. However, in the dry season of the year, there is shortage of pasture for raising heifers, and sugarcane becomes an option, due to its high productivity during this period. However, sugarcane alone does not adequately meet the nutritional requirements of heifers, given that it presents low protein contents, so there is the need to supplement the diet.

Nevertheless, it is known that feeding accounts for the largest part of the cost in the dairy activity and also that excess dietary protein or carbohydrates can lead to imbalance, also resulting in inefficient utilization of the nutrients and low production of microbial protein in ruminants (Nocek \& Russell, 1988). Therefore, balanced diets and of low cost are desirable in the rearing of dairy heifers.

The literature referring to the development and adequate metabolism of crossbred Holstein $\times$ Gir heifers is scarce, mainly when the roughage utilized is sugarcane.

Thus, the objective of this study was to evaluate the effect of increasing contents of crude protein in diets based on sugarcane on the metabolism, efficiency of microbial protein synthesis, concentration of plasma urea and ruminal parameters of crossbred Holstein $\times$ Gir dairy heifers. 


\section{Material and Methods}

The experiment was conducted in the beef cattle raising sector of the Experimental Station of Pólo Regional da Alta Mogiana (Colina/São Paulo, Brazil), unit of Agência Paulista de Tecnologia dos Agronegócios (APTA), located at $21^{\circ} 14^{\prime} 07^{\prime \prime}$ South latitude and $48^{\circ} 16^{\prime} 35^{\prime \prime}$ West longitude. The climate of the region is classified, according to Köepen, as Aw, defined as tropical of rainy summer and dry winter.

Four crossbred Holstein $\times$ Gir dairy heifers of average initial body weight of $200 \mathrm{~kg}$, fistulated in the rumen and duodenum, were utilized for evaluation of the apparent partial digestibility, plasma urea concentration, microbial protein synthesis in the rumen, rumen $\mathrm{pH}$, concentration of short-chain fatty acids and ammonia nitrogen $\left(\mathrm{N}^{-\mathrm{NH}_{3}}\right)$ in the rumen. The experimental design utilized was in a $4 \times 4$ balanced latin square.

The experiment was comprised of four experimental periods, with 26 days in each. The first seven days were utilized for adaptation to the experimental diets, and 19 days were used for collection of data. Experimental diets were constituted of four contents of crude protein $(13 ; 15 ; 19$; and $22 \mathrm{~g} \mathrm{CP} / 100 \mathrm{~g}$ of the total dry matter) (Table 1).

Animals received complex of vitamins ADE and were treated against endo- and ectoparasites 15 days prior to the beginning of the experiment and housed in individual stalls of $12.5 \mathrm{~m}^{2}$ of concrete floor, provided with feeder and drinker.

Animals were fed ad libitum with the diet composed of $70 \%$ roughage and $30 \%$ concentrate, on a dry matter basis, twice daily, at $8 \mathrm{~h} 00$ and $17 \mathrm{~h} 00$. The roughage supplied was forage sugarcane variety IAC86-2480, shredded daily. Due to the work routine in the experimental station, where the sugarcane was chopped once a day, in the beginning of the morning, at the morning feeding, animals received all the roughage and approximately $60 \%$ of the concentrate, whereas in the afternoon feeding, the remainder of the concentrate was mixed to the feed present in the trough, as a strategy for animals to return to the trough and also to diminish the chances of diet fermentation. No fermentation of sugarcane was observed in the trough, during the experiment. The canebrake of IAC86-2480 was implanted in 2005 and, at the moment of the experiment, it was at its second cutting.

The quantities of feed supplied were weighed daily. During the period of data collection, feed intake and leftovers from each animal were also weighed. The daily supply of feed was adjusted at the beginning of each experimental period, enabling leftovers of $10 \%$ of the total supplied.
The duration of data collection for determination of the intake was of five consecutive days halfway through the experimental period, from the 8th to the 12th day. In this period, at the moment of feeding, the feed supplied and the leftovers were sampled and stored at $-15^{\circ} \mathrm{C}$. At the end of each experimental period, a composite sample was made per animal, and subsequently sent to analyses.

The fecal production of dry matter was estimated through the use of external marker CrEDTA given to animals. The adaptation of animals to the marker occurred during five days, from the 13th to the 17th day, performed with provision of $150 \mathrm{~mL}$ of the marker directly in the rumen, diluted in water and homogenized manually. This

Table 1 - Proportion of ingredients in the concentrate and composition in dry matter, nutrients, energy and nitrogenous fractions of the ingredients of the diet

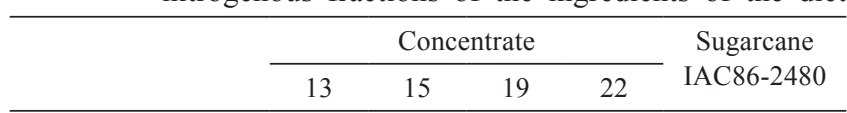

\begin{tabular}{|c|c|c|c|c|c|}
\hline \multicolumn{6}{|c|}{ Proportion (g/kg of natural matter) } \\
\hline Ground corn grain & 678.9 & 471.7 & 264.1 & 55.4 & - \\
\hline Soybean meal & 247.2 & 457.8 & 668.9 & 881.0 & - \\
\hline $\begin{array}{l}\text { Urea }+ \text { ammonium } \\
\text { sulfate }(9: 1)\end{array}$ & 29.6 & 29.7 & 29.7 & 29.8 & - \\
\hline Mineral mix ${ }^{1}$ & 44.3 & 40.9 & 37.4 & 33.9 & - \\
\hline \multicolumn{6}{|c|}{ Chemical composition } \\
\hline Dry matter, g/kg NM & 875 & 878 & 880 & 886 & 323 \\
\hline \multicolumn{6}{|c|}{$\mathrm{g} / \mathrm{kg}$ dry matter } \\
\hline Mineral matter & 50 & 68 & 71 & 83 & 25 \\
\hline Organic matter & 949 & 932 & 929 & 917 & 975 \\
\hline Crude protein & 345 & 431 & 565 & 659 & 33 \\
\hline Nitrogen & 55 & 69 & 90 & 105 & 05 \\
\hline NDIP & 23 & 16 & 14 & 12 & 11 \\
\hline ADIP & 06 & 08 & 10 & 11 & 06 \\
\hline Ether extract & 38 & 30 & 26 & 17 & 07 \\
\hline Neutral detergent fiber & 196 & 181 & 165 & 155 & 435 \\
\hline Acid detergent fiber & 37 & 49 & 61 & 75 & 258 \\
\hline Total carbohydrates & 566 & 471 & 338 & 241 & 934 \\
\hline $\begin{array}{l}\text { Non-fibrous } \\
\text { carbohydrates }\end{array}$ & 370 & 290 & 173 & 86 & 499 \\
\hline Lignin & 16 & 17 & 17 & 18 & 39 \\
\hline Gross energy (kcal/kg) & 4145.2 & 4308.9 & 4352.9 & 4371.3 & 4137.1 \\
\hline \multicolumn{6}{|c|}{$\mathrm{g} / \mathrm{kg}$ total nitrogen ${ }^{2}$} \\
\hline Fraction A & 383 & 290 & 329 & 287 & 423 \\
\hline Fraction B1 & 225 & 173 & 151 & 180 & 96 \\
\hline Fraction B2 & 327 & 500 & 494 & 514 & 135 \\
\hline Fraction B3 & 49 & 19 & 08 & 02 & 192 \\
\hline Fraction $\mathrm{C}$ & 16 & 17 & 18 & 17 & 154 \\
\hline \multicolumn{6}{|c|}{$\begin{array}{l}\text { NM - natural matter; NDIP - neutral detergent insoluble protein; ADIP - acid } \\
\text { detergent insoluble protein. } \\
{ }^{1} \text { Composition in percentage of mineral mix (for } 13,15,19 \text { and } 22 \mathrm{~g} \mathrm{CP} / 100 \mathrm{~g} \text { of } \\
\text { dietary DM, respectively): limestone }(37.8 ; 42.5 ; 48.2 ; 57.1) \text {, dicalcium phosphate } \\
(46.3 ; 41.9 ; 36.6 ; 28.9) \text {, sodium }(7.5 ; 7.8 ; 8.1 ; 8.1) \text {, sulfur }(6.9 ; 6.3 ; 5.5 ; 4.3) \text {, } \\
\text { copper sulfates }(0.27 ; 0.29 ; 0.32 ; 0.34) \text {, zinc }(0.76 ; 0.82 ; 0.90 ; 0.74) \text {, manganese } \\
(0.43 ; 0.47 ; 0.43 ; 0.45) ; \text { cobalt }(0.003 ; 0.003 ; 0.004 ; 0.004) \text {, potassium iodate } \\
(0.003 ; 0.003 ; 0.004 ; 0.004) \text {, sodium selenite }(0.004 ; 0.005 ; 0.005 ; 0.006) \text {. } \\
{ }^{2} \text { Analyzed in laboratory: fraction A - non-protein nitrogen (soluble fraction); fraction } \\
\text { B1 - peptides and oligopeptides (fraction of rapid rumen degradation); fraction } \\
\text { B2 - true protein (intermediate degradability); fraction B3 - protein associated with } \\
\text { the neutral detergent fiber (slow rumen degradability); fraction C - acid detergent } \\
\text { insoluble protein (undegradable). }\end{array}$} \\
\hline
\end{tabular}


administration of the marker occurred before each feeding session ( $8 \mathrm{~h} 00$ and $17 \mathrm{~h} 00$ ), in a total solution (water + marker) of $2 \mathrm{~L} /$ day infused in the rumen.

The collections for the estimation of the DM fecal production of the animals were conducted during two days, on the 18th and 19th days, with collections in the following scheme: on the 1 st day, at $2 \mathrm{~h} 00,8 \mathrm{~h} 00,14 \mathrm{~h} 00$ and $20 \mathrm{~h} 00$, and on the $2 \mathrm{nd}$ day, at $5 \mathrm{~h} 00,11 \mathrm{~h} 00,17 \mathrm{~h} 00$ and 23h00. Samples were collected directly from the rectum of the animals. After collection, samples were stored at $-15{ }^{\circ} \mathrm{C}$, subsequently thawed and ground for analyses. After grinding, a composite sample was formed per animal in each experimental period.

The duodenal flow of dry matter was also estimated with the aid of marker provided to animals. The adaptation of animals to markers occurred during the days of adaptation to the diets, because internal marker iNDF (indigestible neutral detergent fiber) was utilized.

The collections for the estimation of the duodenal DM flow in the animals were performed during two days, on the 20 th and 21 th days, after the days intended for collection of feces, with collections performed as follows: 1 st day at $5 \mathrm{~h} 00$, $8 \mathrm{~h} 00,14 \mathrm{~h} 00$ and $20 \mathrm{~h} 00$ and on the $2 \mathrm{nd}$ day at $2 \mathrm{~h} 00,11 \mathrm{~h} 00$, $17 \mathrm{~h} 00$ and $23 \mathrm{~h} 00$. Samples were collected directly from the cannula of the duodenum of the animals, at the amount of $300 \mathrm{~mL} /$ animal/collection. After collection, samples were immediately frozen at $-15{ }^{\circ} \mathrm{C}$ and later thawed and dried in forced-ventilation oven at $55{ }^{\circ} \mathrm{C}$. After grinding of the samples, a composite sample was formulated per animal in each experimental period, on the basis of dry matter of each sample/time.

Collections of blood were conducted on the 16th and 17 th days of each experimental period. Blood was collected directly from the jugular of heifers, before and four hours after morning feeding, with vacutainer tubes. Immediately after collection, blood samples were chilled in a refrigerator and sent to laboratory analyses. In the laboratory, samples were centrifuged (4193 $\mathrm{x}$ g for 15 minutes) for obtainment of the plasma, and the contents of urea were determined in it via enzymatic system (Doles Reagentes e Equipamentos para Laboratório LTDA, kit Ureia 500).

The rumen fluid was collected on the 25th day of each experimental period for determination of $\mathrm{pH}$, concentration of $\mathrm{N}_{-} \mathrm{NH}_{3}$ and concentrations of short-chain fatty acids (SCFA); collections were done at 0 (before supply of morning feed), 1, 2, 4, 6, 8, 10 and 12 hours after feeding. For so, the rumen content was collected manually through rumen cannula. About $50 \mathrm{~mL}$ collected after filtering through double-layer cotton fabric were sent to immediate determination of $\mathrm{pH}$ on a digital $\mathrm{ph}$ meter. Next, an aliquot of $20 \mathrm{~mL}$ was conditioned in plastic container and stored at $-15{ }^{\circ} \mathrm{C}$ for subsequent determination of the concentrations of $\mathrm{N}-\mathrm{NH}_{3}$. Another aliquot of $20 \mathrm{~mL}$ was also stored at $-15^{\circ} \mathrm{C}$, for subsequent determination of the concentration of the SCFA acetate, propionate and butyrate. The dry content of the sample taken was returned to the rumen right after.

On the 26th day of each experimental period, $1.5 \mathrm{~L}$ of rumen content were collected from each animal for isolation of bacteria, according to technique described by Ushida et al. (1985). Samples were stored after being solubilized with $0.5 \mathrm{~L}$ of saline solution at $-15{ }^{\circ} \mathrm{C}$. Subsequently, samples were centrifuged for separation of the microbial mass in refrigerated centrifuge, following methodology described by Cecava et al. (1990). After lyophilization of the samples, they were sent to analysis for determination in spectrophotometer according to the methodology described by Zinn \& Owens (1986). Purine bases were utilized as marker for estimation of the production of rumen microbial protein.

Samples of feed, leftovers, feces and duodenal digesta were dried in forced-ventilation oven at $55^{\circ} \mathrm{C}$ and ground in knife mill with $5 \mathrm{~mm}$ mesh sieve. Later, half of each sample was ground to $1 \mathrm{~mm}$ (AOAC, 1990). Samples were sent to analyses of dry matter (DM), organic matter (OM), nitrogen $(\mathrm{N})$ and gross energy (GE) according to the AOAC (1990), as described by Silva \& Queiroz (2002), and for conversion into crude protein, the correction factor 6.25 was utilized.

The neutral detergent fiber (NDF) was determined with samples subjected to digestion in detergent solution, according to the method of Van Soest et al. (1991), and acid detergent fiber (ADF), according to the methodology described in Silva \& Queiroz (2002), and with modifications described in Deschamps (1999), in which samples are placed on autoclave at $111{ }^{\circ} \mathrm{C}$ and $0.5 \mathrm{~atm}$ for 5 minutes.

The contents of total carbohydrates $(\mathrm{TCH}) \mathrm{TCH}=$ $100-(\% \mathrm{CP}+\% \mathrm{EE}+\% \mathrm{Ash})$ were calculated according to Sniffen et al. (1992). Non-fibrous carbohydrates (NFC) were calculated through the equation: $\mathrm{NFC}=\mathrm{TCH}-\mathrm{NDF}$.

The residue obtained after $144 \mathrm{~h}$ of in situ incubation was considered the iNDF in the diet, digesta and feces, according to Berchielli et al. (2000). For incubation of the samples of particle size of $5 \mathrm{~mm}, 2$ rumen-cannulated bulls with average body weight of $200 \mathrm{~kg}$ kept in stalls receiving Brachiaria grass supplied in the trough and with mineral salt were utilized. Samples were incubated in duplicate.

Samples of feces and duodenal digesta were subjected to nitro-perchloric digestion according to methodology 
described by De Vega \& Poppi (1997) for further determination of the concentration of $\mathrm{Cr}$ through readings performed on atomic absorption spectrophotometer.

The determination of the concentration of $\mathrm{N}-\mathrm{NH}_{3}$ was conducted by the Kjeldahl method without acid digestion, after distillation with potassium hydroxide $(2 \mathrm{~N})$ and titrated with hydrochloric acid $(0.005 \mathrm{~N})$. Analyzes of the SCFA were conducted according to method recommended by Leventini et al. (1990), by means of gas chromatography (7890-A, Agilent Technologies, Palo Alto, CA, USA), equipped with flame ionization detector (7683B, Agilent Technologies, Palo Alto, CA, USA) and fused silica capillary column DB-WAX (30 m; $0.25 \mathrm{~mm} ; 0.25 \mu \mathrm{m}$ propylene glycol, Agilent Technologies, Palo Alto, CA, USA). The data acquisition was done by means of software ChemStation (Agilent Technologies, Palo Alto, CA, USA).

The results obtained for variables intake, apparent, ruminal and intestinal digestibility, synthesis of microbial efficiency and concentration of plasma urea were subjected to analyses of variance and regression, by utilizing commands PROC GLM and PROC REG of computer program SAS (version 8.2), adopting $\alpha=0.05$. Variables $\mathrm{pH}$, concentration of $\mathrm{N}-\mathrm{NH}_{3}$ and SCFA in the rumen were analyzed as means repeated over time with command PROC MIXED of computer program SAS (version 8.2).

\section{Results and Discussion}

The intake values of dry matter, organic matter and non-fibrous carbohydrates were not different $(\mathrm{P}>0.05)$ between the contents of 13,15, 19 and $22 \mathrm{CP} / 100 \mathrm{~g}$ DM in the diet, whereas the variables intake of crude protein and ether extract were different $(\mathrm{P}<0.05)$ between diets (Table 2$)$.
The dry matter and nutrient intake in the animals for the metabolism trial can be affected by the stressful handling of the collections when compared with the dry matter and nutrient intake of animals on performance. The DMI averages observed in this experiment were of $5.0 \mathrm{DM} /$ day, corresponding to $21 \mathrm{~g} / \mathrm{kg}$ of body weight and $82 \mathrm{~g}$ /day when expressed in metabolic live weight. These values are similar to those reported by Miranda et al. (1999), who worked with $80 \%$ sugarcane in the diet for crossbred heifers and reported average intake of $19.8 \mathrm{~g} / \mathrm{kg}$ of body weight when utilizing urea as source of non-protein nitrogen, and average intake of $23 \mathrm{~g} / \mathrm{kg}$ of body weight when utilizing chicken bedding in the diet.

When the neutral detergent fiber intake was expressed in $\mathrm{kg} / \mathrm{day}$, an increasing linear behavior $(\mathrm{P}<0.05)$ could be observed as the protein content of the diet was increased. The same increasing linear relation can be observed between the increase in the level of protein in the diet and the $\mathrm{CP}$ intake in kilograms, and also when expressed in metabolic live weight (Table 2).

The decreasing linear behavior of ether extract intake (Table 2) can be considered a result of the composition of the diet, once, as the amount of corn in the diet decreased, the quantity of soybean was elevated, rather than as an alteration in animal intake by the level of protein in the diet.

Significant difference can be observed in the apparent digestibility of dry matter, organic matter and crude protein in the diets containing increasing levels of $\mathrm{CP}$ in their composition (Table 3). The highest averages of total dry matter digestibility in the gastrointestinal tract were observed with the levels of 15 and $13 \mathrm{~g} \mathrm{CP} / 100 \mathrm{~g}$ DM of the diet, coefficients of 0.650 and 0.647 , respectively. There was a decreasing linear behavior in the apparent

Table 2 - Means of intake values of dry matter, organic matter, neutral detergent fiber, non-fibrous carbohydrates, crude protein and ether extract of crossbred heifers fed different levels of protein in the diet

\begin{tabular}{|c|c|c|c|c|c|c|c|c|}
\hline & \multicolumn{4}{|c|}{ Protein content of the diet (g/100 g of DM) } & \multirow{2}{*}{$\mathrm{CV}(\%)$} & \multicolumn{3}{|c|}{$P$ value } \\
\hline & 13 & 15 & 19 & 22 & & Linear & Quadratic & Lack of fit \\
\hline Dry matter (kg/day) & 4.8 & 4.8 & 5.2 & 5.3 & 10.3 & 0.1440 & 0.7749 & 0.5789 \\
\hline $\mathrm{g} / \mathrm{kg} \mathrm{BW}$ & 21.0 & 20.0 & 21.0 & 22.0 & 13.1 & 0.4462 & 0.6906 & 0.7921 \\
\hline $\mathrm{BW}^{0.75}$ & 79.9 & 78.7 & 83.3 & 86.1 & 12.4 & 0.3466 & 0.7086 & 0.7509 \\
\hline Organic matter (kg/day) & 4.6 & 4.6 & 5.0 & 5.1 & 10.3 & 0.1837 & 0.7711 & 0.5568 \\
\hline $\mathrm{g} / \mathrm{kg} \mathrm{BW}$ & 20.0 & 19.0 & 20.0 & 21.0 & 13.2 & 0.5254 & 0.6871 & 0.7729 \\
\hline $\mathrm{BW}^{0.75}$ & 76.9 & 75.3 & 79.5 & 81.8 & 12.5 & 0.4171 & 0.7052 & 0.7308 \\
\hline Neutral detergent fiber $(\mathrm{kg} / \text { day })^{\mathrm{a}}$ & 1.7 & 1.7 & 1.9 & 1.9 & 8.1 & 0.0439 & 0.8787 & 0.4700 \\
\hline $\mathrm{g} / \mathrm{kg} \mathrm{BW}$ & 7.0 & 7.0 & 8.0 & 8.0 & 10.0 & 0.2108 & 0.9044 & 0.7405 \\
\hline Non-fibrous carbohydrat (kg/day) & 2.2 & 2.0 & 1.9 & 1.8 & 13.4 & 0.0658 & 0.8528 & 0.8485 \\
\hline $\mathrm{g} / \mathrm{kg} \mathrm{BW}$ & 9.0 & 8.0 & 8.0 & 7.0 & 17.6 & 0.0774 & 0.7695 & 0.9806 \\
\hline Crude protein $(\mathrm{kg} / \mathrm{day})^{\mathrm{b}}$ & 0.67 & 0.77 & 1.08 & 1.31 & 10.7 & $<0.0001$ & 0.2788 & 0.2421 \\
\hline $\mathrm{BW}^{0.75 \mathrm{c}}$ & 11.05 & 12.66 & 17.44 & 21.23 & 10.3 & $<0.0001$ & 0.2313 & 0.3314 \\
\hline Ether extract $(\mathrm{kg} / \text { day })^{\mathrm{d}}$ & 0.09 & 0.07 & 0.07 & 0.06 & 11.6 & 0.0139 & 0.7973 & 0.2278 \\
\hline
\end{tabular}

$\mathrm{CV}$ - coefficient of variation; DM - dry matter; BW - body weight.

${ }^{\mathrm{a}} \hat{Y}=1.34529+0.02707 \times \mathrm{X}\left(\mathrm{r}^{2}=0.10\right) ;{ }^{\mathrm{b}} \hat{Y}=-0.30289+0.07306 \times \mathrm{X}\left(\mathrm{r}^{2}=0.72\right) ;{ }^{\mathrm{c}} \hat{Y}=-4.17809+1.14635 \times \mathrm{X}\left(\mathrm{r}^{2}=0.82\right) ;{ }^{\mathrm{d}} \hat{Y}=0.11839-0.00281 \times \mathrm{X}\left(\mathrm{r}^{2}=0.36\right)$. 
digestibility of DM in relation to the protein content of the diet; the lowest value was observed in the diet containing $19 \mathrm{~g} \mathrm{CP} / 100 \mathrm{~g} \mathrm{DM}$ (0.559); and the diet with $22 \mathrm{~g} \mathrm{CP} / 100 \mathrm{~g} \mathrm{DM}$ had average coefficient of 0.583 . These values are below the mean values recommended by Mendonça et al. (2004), between 0.670 and 0.698, when evaluating diets based on sugarcane for lactating dairy cows. However, they are superior to the values reported by Silveira et al. (2009), when evaluating sources of nitrogen in diets based on sugarcane, with apparent digestibility of DM averages between 0.509 in diets with sugarcane + urea and 0.598 in diets with sugarcane + soybean meal, which are values close to those observed in the experiment, when evaluating diets containing both urea and soybean meal in their composition, especially in diets which contained higher amount of soybean meal (19 and $22 \mathrm{~g} \mathrm{CP} / 100 \mathrm{~g}$ DM in the diet).

The same linear relation can be observed between the apparent digestibility of organic matter and the level of CP in the diet, with the highest values observed with 15 and 13 $\mathrm{CP} / 100 \mathrm{~g} \mathrm{DM}$ in the diet, both with the coefficient of 0.661 ; and the lowest OMD observed for the diet containing 19 $\mathrm{g} \mathrm{CP} / 100 \mathrm{~g} \mathrm{DM}, 0.575$. The diet with $22 \mathrm{~g} \mathrm{CP} / 100 \mathrm{~g} \mathrm{DM}$ presented, on average, this value was of $0.596 \mathrm{~g} / \mathrm{g}$. The better results in the digestibility of diets containing 13 and $15 \mathrm{~g} \mathrm{CP} / 100 \mathrm{~g} \mathrm{DM}$ can be attributed to a possible adequate synchronization in the supply of energy and protein in the rumen, given that the diets had the same amount of urea in their formulation; however, diets containing 13 and $15 \mathrm{~g} \mathrm{CP} /$ $100 \mathrm{~g} \mathrm{DM}$ had a higher quantity of non-fiber carbohydrates in their composition. However, the results observed in apparent digestibility of crude protein are possibly a consequence of the slow degradation rate of the protein of soybean meal, which, combined with carbohydrates of slow degradation (Table 1), promoted better use of the CP of the diet, thus enabling better digestibility of the diets with higher protein contents in detriment of the diets in which, after utilization of the carbohydrates of rapid degradation, there was damage in the synchronization between energy and protein.

However, in the apparent digestibility of the neutral detergent fibers, there was no difference $(\mathrm{P}>0.05)$ between the protein levels of $13,15,19$ and $22 \mathrm{CP} / 100 \mathrm{~g}$ DM of the diet (Table 3).

There was effect of the levels of protein in the diet $(\mathrm{P}<0.05)$ on the ruminal digestibility of dry matter and absence of difference between the levels of protein in the diet on the ruminal digestibility of organic matter, crude protein and neutral detergent fiber.

In the ruminal digestibility of the dry matter, decreasing linear behavior was observed with the protein content of the diet. Once again, the highest digestibility average can be observed for the diet containing $15 \mathrm{~g} \mathrm{CP} / 100 \mathrm{~g} \mathrm{DM}$, and the lowest average for the diet containing $19 \mathrm{~g} \mathrm{CP} / 100 \mathrm{~g}$ $\mathrm{DM}$ in the composition, and between 86.7 and $89.1 \%$ of the total DM were digested in the rumen.

Table 3 - Means of the total apparent, ruminal and post-ruminal coefficient of digestibility (\%) of nutrients and efficiency of microbial synthesis in crossbred heifers fed different levels of protein in the diet

\begin{tabular}{|c|c|c|c|c|c|c|c|c|}
\hline & \multicolumn{4}{|c|}{ Protein content of the diet (g/100 g DM) } & \multirow{2}{*}{ CV (\%) } & \multicolumn{3}{|c|}{ P value } \\
\hline & 13 & 15 & 19 & 22 & & Linear & Quadratic & Lack of fit \\
\hline \multicolumn{9}{|c|}{ Total apparent digestibility } \\
\hline Dry matter ${ }^{1}$ & 64.7 & 65.0 & 55.9 & 58.3 & 5.3 & 0.0077 & 0.5271 & 0.0266 \\
\hline Organic matter ${ }^{2}$ & 66.1 & 66.1 & 57.5 & 59.6 & 5.2 & 0.0285 & 0.7564 & 0.0405 \\
\hline Crude protein ${ }^{3}$ & 67.3 & 67.6 & 69.2 & 74.9 & 5.6 & 0.0318 & 0.2192 & 0.7667 \\
\hline Neutral detergent fiber & 45.4 & 48.4 & 44.4 & 45.7 & 7.0 & 0.6944 & 0.6246 & 0.1968 \\
\hline \multicolumn{9}{|c|}{ Ruminal apparent digestibility } \\
\hline Dry matter ${ }^{4}$ & 56.1 & 57.4 & 49.8 & 50.7 & 6.6 & 0.0228 & 0.8972 & 0.0668 \\
\hline Organic matter & 58.0 & 59.6 & 52.4 & 55.1 & 5.8 & 0.0749 & 0.7364 & 0.0418 \\
\hline Crude protein & 41.5 & 48.0 & 45.1 & 52.9 & 12.7 & 0.1222 & 0.8536 & 0.2517 \\
\hline Neutral detergent fiber & 43.9 & 49.7 & 42.4 & 43.8 & 8.9 & 0.4237 & 0.3146 & 0.0512 \\
\hline \multicolumn{9}{|c|}{ Post-ruminal apparent digestibility } \\
\hline Dry matter & 8.6 & 7.5 & 6.1 & 7.7 & 16.4 & 0.1658 & 0.0756 & 0.2648 \\
\hline Organic matter ${ }^{5}$ & 6.7 & 6.5 & 5.1 & 4.4 & 8.7 & 0.0003 & 0.3978 & 0.1339 \\
\hline Crude protein & 30.8 & 25.9 & 24.1 & 22.0 & 25.2 & 0.1022 & 0.6790 & 0.8140 \\
\hline Neutral detergent fiber & 1.4 & 0.9 & 2.0 & 1.9 & 68.3 & 0.3453 & 0.7489 & 0.2703 \\
\hline \multicolumn{9}{|c|}{ Efficiency of microbial synthesis } \\
\hline $\mathrm{gN} / \mathrm{kg}$ OMADR & 35.7 & 52.6 & 27.6 & 23.7 & 70.0 & 0.2522 & 0.3267 & 0.2518 \\
\hline gN/Mcal RDE & 0.28 & 0.35 & 0.25 & 0.24 & 50.6 & 0.1475 & 0.1507 & 0.0490 \\
\hline
\end{tabular}

RDE - rumen-digestible energy; OMADR - organic matter apparently digested in the rumen

${ }^{1} \hat{Y}=77.00007-0.93255 \times \mathrm{X}\left(\mathrm{r}^{2}=0.3\right) ;{ }^{2} \hat{Y}=78.19401-0.92267 \times \mathrm{X}\left(\mathrm{r}^{2}=0.36\right) ;{ }^{3} \hat{Y}=57.22384+0.75161 \times \mathrm{X}\left(\mathrm{r}^{2}=0.35\right) ;{ }^{4} \hat{Y}=69.97559-0.92790 \times \mathrm{X} \times\left(\mathrm{r}^{2}=0.28\right) ;{ }^{5} \hat{Y}=10.20245$ $-0.27163 \times \mathrm{X}\left(\mathrm{r}^{2}=0.14\right)$. 
Significant effects of the increasing levels of protein in the diet were observed only in the post-ruminal digestibility of organic matter, whereas in the post-ruminal digestibility of dry matter, crude protein and neutral detergent fiber, no significant effects of the protein content of the diet were observed $(\mathrm{P}>0.05)$.

Increasing linear behavior was observed between the protein content of the diet and the total apparent digestibility of the crude protein, with coefficients of 0.673 ; 0.676 ; 0.692 ; and 0.749 , respectively, in the diets with 13 , 15,19 and $22 \mathrm{~g} \mathrm{CP} / 100 \mathrm{~g} \mathrm{DM}$. However, in the ruminal digestibility of crude protein, no statistical differences $(\mathrm{P}<0.05)$ were observed between the levels of protein of the diet, only numerical differences. The averages of ruminal digestibility of crude protein in relation to the total digestibility of the tract were $0.616 ; 0.710 ; 0.652$; and 0.706 for the diets containing 13,15, 19 and $22 \mathrm{~g} \mathrm{CP} / 100 \mathrm{~g} \mathrm{DM}$ in their composition, which demonstrates that even lower levels of protein can be as well-used as the highest level of protein in the animal organisms provided that they are utilized correctly, respecting the synchronization between energy and protein.

The total apparent and ruminal digestibility values of the neutral detergent fiber were similar between the diets $(\mathrm{P}>0.05)$, with coefficients of 0.463 in the apparent digestibility of NDF and of 0.450 for ruminal digestibility of NDF.

No effect of the protein content of the diet was observed on the efficiency of microbial protein synthesis, in $\mathrm{g} \mathrm{N} / \mathrm{kg}$ of OM apparently digested in the rumen or $\mathrm{g}$ N/Mcal of rumendigestible energy (Table 3). However, the absence of effect of the crude protein contents in the diet on efficiency of microbial protein synthesis is more related to the variation in the results, because the coefficient of variation was at around $70 \%$, rather than due to the equality between the values observed for the efficiency of microbial protein synthesis between diets (Table 3).

The efficiency of microbial protein synthesis values observed in this experiment were inferior, but close to those reported by Silveira et al. (2009), in a study with sugarcane; sugarcane + urea; sugarcane + corn gluten; and sugarcane + soybean meal, with averages of $0.68 ; 0.52 ; 0.99$ and
$0.33 \mathrm{~g} \mathrm{~N} /$ Mcal of ruminal digestible energy, respectively. These authors also reported values of 19.6; 16.2; 19.9; and 20.1 when expressed in $\mathrm{g} \mathrm{N} / \mathrm{kg}$ OM apparently digested in the rumen, which are superior, but close to the observed in the present study. According to Silveira et al. (2009), the different sources of rumen-degradable nitrogen evaluated do not affect the synthesis of microbial protein.

According to Santos (2006), in the rumen, the NFC withstand more microbial production than the fibrous carbohydrates, because of the greater rate and extension of degradation. In the present study, in the diets containing 13 and $15 \mathrm{~g} \mathrm{CP} / 100 \mathrm{~g} \mathrm{DM}$, the participation of the NFC was greater than in the diets containing 19 and $22 \mathrm{~g} \mathrm{CP} / 100$ g DM (Table 1), so they enabled efficiency of microbial protein synthesis about 50 and $120 \%$ higher for the contents of 13 and $15 \mathrm{~g} \mathrm{CP} / 100 \mathrm{~g} \mathrm{DM}$ when compared with the level of $22 \mathrm{~g} \mathrm{CP} / 100 \mathrm{~g}$ DM in the diet. These results demonstrate that in the treatments with the highest contents of $\mathrm{CP}$, due to the composition of the diet (Table 1), there was no synchronization of the fermentation of carbohydrates and proteins, preventing efficiency of microbial synthesis at more elevated levels of $\mathrm{CP}$ in the diet from being reached.

There was statistical difference $(\mathrm{P}<0.05)$ in the averages of concentration of plasma urea of heifers receiving increasing levels of CP in the diet (Table 4), both in the concentration before feeding $(0 \mathrm{~h})$ and $4 \mathrm{~h}$ after feeding, demonstrating increasing linear relation with the protein contents of the diet.

At the time $0 \mathrm{~h}$ after feeding, the concentration of plasma urea nitrogen in the blood was, on average, 12.0; 13.6; 16.7; and $16.16 \mathrm{mg} / \mathrm{dL}$ for treatments $13,15,19$ and $22 \mathrm{CP} / 100 \mathrm{~g} \mathrm{DM}$, respectively, whereas 4 hours after feeding, higher plasma levels were observed in all protein contents of the diets, reaching averages of 13.4; 15.3; 18.5 ; and $19.3 \mathrm{mg} / \mathrm{dL}$ at the levels of $13,15,19$ and $22 \mathrm{~g}$ $\mathrm{CP} / 100 \mathrm{~g} \mathrm{DM}$, respectively. The increase in the level of circulating nitrogen after feeding of animals is a result of the fermentation products. The increases observed were approximately 10,11, 13 and $30 \%$ superior to those found before feeding, respectively, for the levels 13, 15, 19 and $22 \mathrm{~g} \mathrm{CP} / 100 \mathrm{~g}$ DM of the diet.

Table 4 - Means of the concentration of plasma urea nitrogen before (0h) and after (4h) feeding of crossbred heifers with different levels of protein in the diet

\begin{tabular}{|c|c|c|c|c|c|c|c|c|}
\hline & \multicolumn{4}{|c|}{ Protein content of the diet (g/100 g DM) } & \multirow{2}{*}{$\mathrm{CV}(\%)$} & \multicolumn{3}{|c|}{$\mathrm{P}$ value } \\
\hline & 13 & 15 & 19 & 22 & & Linear & Quadratic & Lack of fit \\
\hline Urea $0 \mathrm{~h}(\mathrm{mg} / \mathrm{dL})^{1}$ & 12.5 & 13.6 & 15.8 & 15.2 & 13.2 & 0.0121 & 0.2955 & 0.2688 \\
\hline Urea $4 \mathrm{~h}(\mathrm{mg} / \mathrm{dL})^{2}$ & 13.8 & 15.1 & 17.9 & 19.8 & 13.1 & 0.0053 & 0.6304 & 0.4897 \\
\hline
\end{tabular}

$\mathrm{DM}$ - dry matter; $\mathrm{CV}$ - coefficient of variation.

${ }^{1} \hat{Y}=6.11076+0.49303 \times \mathrm{X}\left(\mathrm{r}^{2}=0.21\right) ;{ }^{2} \hat{Y}=5.14333+0.66683 \times \mathrm{X}\left(\mathrm{r}^{2}=0.41\right)$. 
The ammonia non-assimilated by the microorganisms is usually absorbed by the rumen wall, removed from the portal circulation by the liver, entering the urea cycle (Lobley et al., 1995). When the rate of ammonia synthesis is higher than its utilization by the microorganisms, there is elevation in the concentration in the rumen, with consequent increase in the excretion and in the energy cost of production of urea, resulting in loss of protein (Russell et al., 1992).

Hall et al. (1995) reported that the plasma urea concentration is related to the ingestion of CP in the diet of beef steers, as also verified by Gabler \& Heinrichs (2003) in Holstein heifers. Thus, because in this experiment the DM and $\mathrm{OM}$ intake in percentage of body weight was constant between the diets (Table 2), the increase in the concentration of plasma urea can be attributed exclusively to the different CP contents of the diet. Since the protein of the diet was of vegetable origin, with high rumen degradability, the elevated contents of plasma urea verified are caused by the rumen degradation of the protein of the diet. With the utilization of protected proteins in the diet or with protein of animal origin, such high values would probably not be observed in the concentration of plasma urea.

There was no difference in the values of rumen $\mathrm{pH}$ between the increasing levels of $\mathrm{CP}$ in the diet $(\mathrm{P}>0.05)$ (Table 5) or interaction between time of collection and $\mathrm{CP}$ content $(\mathrm{P}>0.05)$ in the diet. However, there was effect of time of collection $(\mathrm{P}<0.05)$, with a drop in the $\mathrm{pH}$ values observed between $0 \mathrm{~h}$ (before animal feeding) and $1 \mathrm{~h}$ after feeding at all the levels of protein in the diet (Figure 1). However, $1 \mathrm{~h}$ after feeding $\mathrm{pH}$ averages were similar to those obtained at 2 and $8 \mathrm{~h}$ after feeding. It was possible to observe the lower rumen $\mathrm{pH}$ value $10 \mathrm{~h}$ after animal feeding.

Daytime variations in the rumen $\mathrm{pH}$ values are, according to Devant et al. (2000), a result of the DM intake and the rates of carbohydrate digestion in the diet. The averages of $\mathrm{pH}$ values in this experiment were above 6.0 in all the levels of CP in the diet, which did not affect the fiber digestibility (Table 3 ).
The concentration of rumen ammonia nitrogen (Table 5) was affected $(\mathrm{P}<0.05)$ by the level of protein in the diet, with the highest averages observed for 19 and $22 \mathrm{~g} \mathrm{CP} /$ $100 \mathrm{~g}$ DM of the diet (27.5 and $31.6 \mathrm{mg} / \mathrm{dL}$, respectively), average of $21.1 \mathrm{mg} / \mathrm{dL}$ for the diet with $15 \mathrm{~g} \mathrm{CP} / 100 \mathrm{~g} \mathrm{DM}$ and the lowest average observed for the diet containing $13 \mathrm{~g} \mathrm{CP} / 100 \mathrm{~g} \mathrm{DM}, 14 \mathrm{mg} / \mathrm{dL}$ (Table 5). There was effect of the time of collection on the rumen concentration of $\mathrm{N}-\mathrm{NH}_{3}$

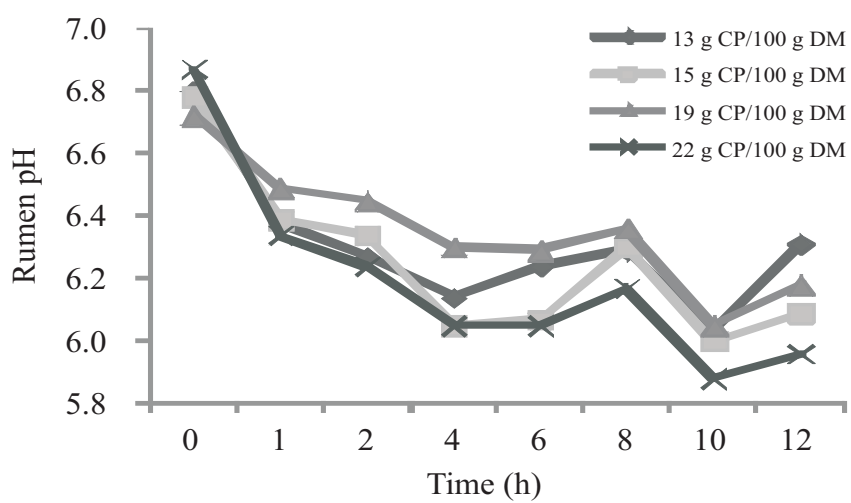

Figure 1 - Means of rumen $\mathrm{pH}$ of diets with increasing levels of crude protein ( $\mathrm{g}$ of CP/100 $\mathrm{g}$ of $\mathrm{DM}$ ) at collection times $0,1,2,4,6,8,10$ and 12 hours after feeding.

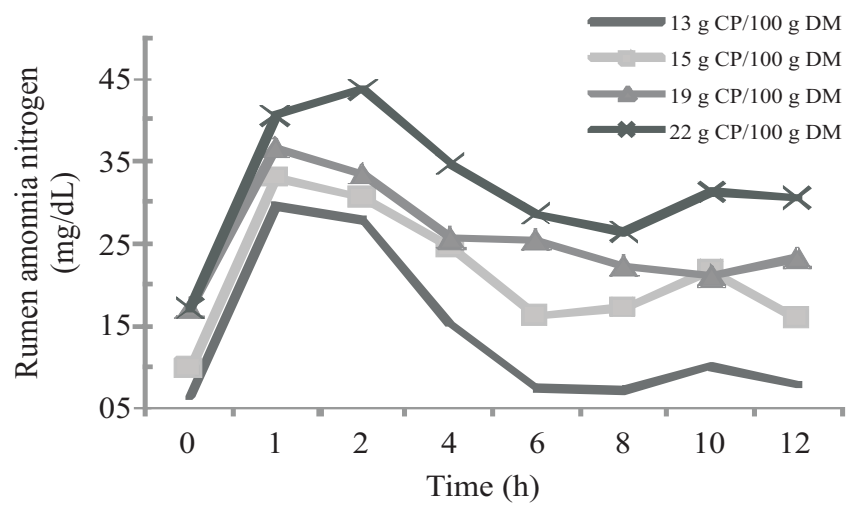

Figure 2 - Means of rumen ammonia nitrogen $(\mathrm{mg} / \mathrm{dL})$ of diets with increasing levels of crude protein $(\mathrm{g}$ of $\mathrm{CP} / 100 \mathrm{~g}$ of DM) at collection times $0,1,2,4,6,8,10$ and 12 hours after feeding.

Table 5 - Means of $\mathrm{pH}$, ammonia nitrogen and short-chain fatty acids in crossbred heifers fed different levels of protein in the diet

\begin{tabular}{|c|c|c|c|c|c|c|}
\hline & \multicolumn{4}{|c|}{ Protein content of the diet (g/100 g DM) } & \multirow{2}{*}{$\mathrm{CV}(\%)$} & \multirow{2}{*}{$\frac{\text { P value }}{\text { Treatment }}$} \\
\hline & 13 & 15 & 19 & 22 & & \\
\hline $\mathrm{pH}$ & 6.3 & 6.3 & 6.4 & 6.2 & 2.0 & 0.0896 \\
\hline Ammonia nitrogen (mg/dL) & $14.0 \mathrm{c}$ & $21.1 \mathrm{~b}$ & $27.5 \mathrm{a}$ & $31.6 \mathrm{a}$ & 21.7 & $<0.0001$ \\
\hline Total short-chain fatty acids $(\mathrm{mmol} / \mathrm{L})$ & $101.3 b$ & $108.7 \mathrm{a}$ & $108.9 \mathrm{a}$ & $113.3 \mathrm{a}$ & 6.4 & 0.0069 \\
\hline Acetate $(\mathrm{mmol} / \mathrm{L})$ & 65.9 & 72.5 & 69.3 & 70.0 & 11.8 & 0.1050 \\
\hline Propionate $(\mathrm{mmol} / \mathrm{L})$ & $22.0 \mathrm{~b}$ & $22.2 b$ & $24.7 \mathrm{ab}$ & $27.4 \mathrm{a}$ & 16.3 & 0.0312 \\
\hline Butyrate $(\mathrm{mmol} / \mathrm{L})$ & $13.5 b$ & $13.9 \mathrm{~b}$ & $14.8 \mathrm{ab}$ & $15.8 \mathrm{a}$ & 7.5 & 0.0311 \\
\hline Acetate:propionate ratio & 3.6 & 4.2 & 3.3 & 3.0 & 45.7 & 0.2418 \\
\hline
\end{tabular}

DM - dry matter; CV - coefficient of variation. 
$(\mathrm{P}<0.05)$ (Figure 2). There was no interaction between time of collection and $\mathrm{CP}$ content $(\mathrm{P}>0.05)$ in the diet.

The average concentration of rumen ammonia nitrogen in animals fed the diet containing $22 \mathrm{~g} \mathrm{CP} / 100 \mathrm{~g}$ DM presented its peak 2 hours after feeding $(43.6 \mathrm{mg} / \mathrm{dL})$, as a consequence of greater amount of CP in kilograms ingested by animals in this treatment, whereas the other treatments had peaks of concentration 1 hour after feeding $(29.6 ; 32.9$; and $36.6 \mathrm{mg} / \mathrm{dL}$ for 13,15 and $19 \mathrm{~g} \mathrm{CP} / 100 \mathrm{~g} \mathrm{DM}$ of the diet, respectively). The peak of $\mathrm{N}^{-\mathrm{NH}_{3}}$ observed 2 hours after feeding for the content of $22 \mathrm{~g} \mathrm{CP} / 100 \mathrm{~g} \mathrm{DM}$ of the diet is a result of the greater concentration of nitrogen in this treatment, confirming the results reported by Tibo et al. (2000) of linear increase in

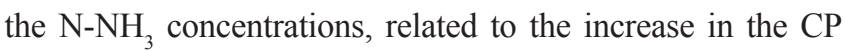
intake at the higher levels of concentrate in the diets.

Gabler \& Heinrichs (2003) reported peaks of rumen concentration of $\mathrm{N}_{-} \mathrm{NH}_{3}$ between 2 and 2.5 hours after feeding, in Holstein heifers fed between 12 and $20 \mathrm{~g} \mathrm{CP} / 100 \mathrm{~g} \mathrm{DM}$ in the diet. However, these authors did not measure the

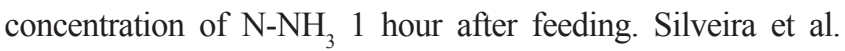
(2009) reported average concentrations of rumen $\mathrm{N}_{-} \mathrm{NH}_{3}$ of $18.09 ; 66.86 ; 27.90$ and $39.24 \mathrm{mg} \mathrm{N}-\mathrm{NH}_{3} / \mathrm{dL}$ of rumen fluid, respectively, in animals maintained on diets with sugarcane; sugarcane + urea; sugarcane + corn gluten; and sugarcane + soybean meal.

In the present study, the averages of concentration of rumen $\mathrm{N}^{-\mathrm{NH}_{3}}$ were above $5 \mathrm{mg} / \mathrm{dL}$, as recommended as minimum by Satter \& Slyter (1974), and the recommended by Leng (1990), superior to $10 \mathrm{mg} / \mathrm{dL}$ (except for the diet containing $13 \mathrm{~g} \mathrm{CP} / 100 \mathrm{~g} \mathrm{DM}$ ) at all times of collection evaluated. However, even at the level of $13 \mathrm{~g} \mathrm{CP} / 100 \mathrm{~g}$ $\mathrm{DM}$, the digestion of fiber was not affected by the lower concentration of $\mathrm{N}^{-\mathrm{NH}_{3}}$, with similar averages observed for the NDF digestibility in all diets (Table 3).

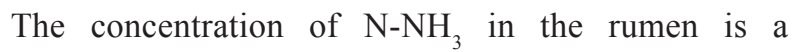
consequence of the balance between its production, absorption and utilization by microorganisms. The utilization efficiency of ammonia by the microorganisms for the microbial synthesis depends, among other factors, on the availability of energy in the rumen (Santos, 2006), thus withstanding greater microbial growth (Russel et al., 1992). Rumen bacteria utilize rumen $\mathrm{N}-\mathrm{NH}_{3}$ as a source of nitrogen for the synthesis of microbial protein, but the rumen fermentation of the protein usually produces more rumen ${\mathrm{N}-\mathrm{NH}_{3}}_{3}$ than the microorganisms can utilize. In the diet containing $22 \mathrm{~g} \mathrm{CP} / 100 \mathrm{~g} \mathrm{DM}, 2 \mathrm{~h}$ after feeding, there was probably waste of rumen ammonia, causing an extra cost to the animal for the absorption in the rumen wall and subsequent excretion of this excess in the environment. This possibility is corroborated by the plasma urea concentration observed in heifers when consuming this diet (Table 4).

As for the ruminal concentration of short-chain fatty acids (SCFA; Table 5), there was no significant interaction between time of collection and CP content in the diet $(\mathrm{P}>0.05)$, as well as no effect of time of collection $(\mathrm{P}>0.05)$ on its concentration. However, there was effect of the protein content of the diet $(\mathrm{P}=0.0069)$ on the total ruminal concentration of SCFA (Table 5).

The lowest level of protein in the diet, $13 \mathrm{~g} \mathrm{CP} / 100 \mathrm{~g} \mathrm{DM}$, promoted lower concentration of total SCFA in the rumen of heifers, with an average of $101.3 \mathrm{mmol} / \mathrm{L}$, significantly different from the other levels of protein, which did not differ from each other, with values of $108.7 ; 108.9$; and $113.3 \mathrm{mmol} / \mathrm{L}$, respectively, in diets containing 15,19 and $22 \mathrm{~g} \mathrm{CP} / 100 \mathrm{~g} \mathrm{DM}$ (Table 5).

The concentration of acetic acid was similar $(\mathrm{P}>0.05)$ between the different levels of protein of the diets, with ruminal concentrations in all diets supplied remaining between 66 and $73 \mathrm{mmol} / \mathrm{L}$ of rumen content. However, the concentrations of propionate and butyrate were different $(\mathrm{P}<0.05)$ in the rumen of animals fed increasing levels of $\mathrm{CP}$ in the diet. For both, the concentrations were superior in the diet containing $22 \mathrm{~g} \mathrm{CP} / 100 \mathrm{~g} \mathrm{DM}$. In the diets with $19 \mathrm{~g} \mathrm{CP} / 100 \mathrm{~g} \mathrm{DM}$, the concentrations observed were not different from those observed with 13 and $15 \mathrm{~g} \mathrm{CP} / 100 \mathrm{~g}$ DM of the diet (Table 5). The results observed in the present study differ from those reported by Devant et al. (2000), in which the total SCFA was not affected by the level of protein in the diet (17 and $14 \mathrm{~g} \mathrm{CP} / 100 \mathrm{~g} \mathrm{DM})$ in Holstein heifers of $101 \mathrm{~kg}$ average body weight. However, these authors worked with contents above $14 \mathrm{~g} \mathrm{CP} / 100 \mathrm{~g} \mathrm{DM}$ of the diet and, in the present study, only the level of $13 \mathrm{~g}$ $\mathrm{CP} / 100 \mathrm{~g} \mathrm{DM}$ of the diet was different from the others, so Devant et al. (2000) might have found different values for the total SCFA had they utilized lower contents of CP in the diets for Holstein heifers.

The acetate:propionate ratio was not statistically influenced by the protein content of the $\operatorname{diet}(\mathrm{P}>0.05)$ or by the interaction between time of collection and $\mathrm{CP}$ content of the diet $(\mathrm{P}>0.05)$ (Figure 3). However, as expected, the acetate:propionate ratio was affected by the time of collection $(\mathrm{P}<0.05)$ (Figure 3); the lowest ratio was observed between 1 and 2 hours after the consumption of concentrate by heifers, when the highest ruminal concentration of $\mathrm{N}-\mathrm{NH}_{3}$ was observed. The maintenance in the proportions of the two acids can be explained by the composition of the diet, which contained the same ingredients and also the same roughage:concentrate ratio. 


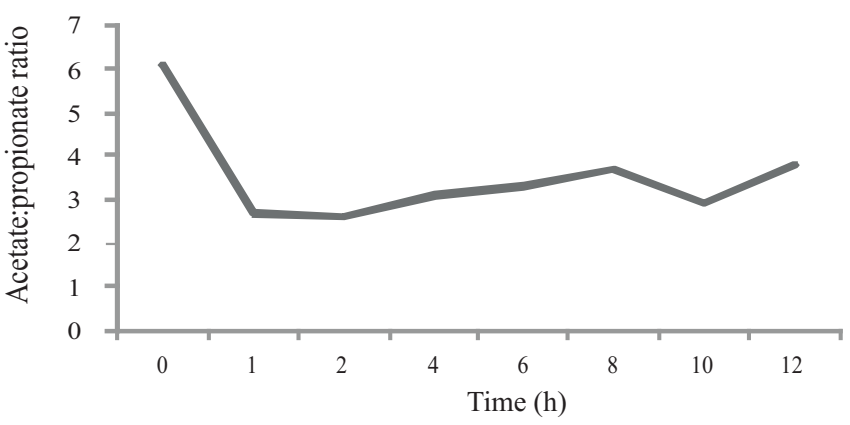

Figure 3 - Acetate:propionate ratio in the rumen in diets with increasing levels of crude protein.

The acetate:propionate ratio can serve as an indicator of the efficiency of the ruminal utilization of energy. The same acetate:propionate ratio observed can indicate similar production of methane and similar utilization efficiency of the energy of the feed ingested by animals, although the diets have different protein contents.

\section{Conclusions}

It is recommended to utilize $13 \mathrm{~g}$ of $\mathrm{CP} / 100 \mathrm{~g}$ of $\mathrm{DM}$ of the diet for crossbred Holstein $\times$ Gir heifers at postweaning consuming diets based on sugarcane, because this level propitiates increase in the diet digestibility and lower concentrations of plasma urea nitrogen and ammonia nitrogen, demonstrating better metabolism of animals, in addition to decrease in the cost of the diet.

\section{References}

ASSOCIATION OF OFFICIALANALYTICAL CHEMISTS - AOAC. Official methods of analysis. 15.ed. Arlington: Kenneth Helrich, 1990. 2v. 1990. 1298p.

BERCHIELLI, T.T.; ANDRADE, P.; FURLAN, C.L. Avaliação de indicadores internos em ensaios de digestibilidade. Revista Brasileira de Zootecnia, v.29, n.3, p.830-833, 2000.

CECAVA, M.J.; MERCHEN, N.R.; GAY, L.C. et al. Composition of ruminal bacteria harvested from steers as influenced by dietary energy level, feeding frequency and isolation techniques. Journal of Dairy Science, v.73, n.9, p.2480-2488, 1990.

De VEGA, A.G.; POPPI, D.P. Extent of digestion and rumen condition as factors affecting passage of liquid and digesta particles in sheep. Journal of Agricultural Science, v.128, p.207-215, 1997.

DESCHAMPS, F.C. Implicações do período de crescimento na composição química e digestão dos tecidos de cultivares de capim elefante. Revista Brasileira de Zootecnia, v.28, n.6, p.1178-1189, 1999.

DEVANT, M.; FERRET, A.; GASA, J. et al. Effects of protein concentration and degradability on performance, ruminal fermentation, and nitrogen metabolism in rapidly growing heifers fed high-concentrate diets from 100 to $230 \mathrm{~kg}$ body weight. Journal of Animal Science, v.78, n.6, p.1667-1676, 2000.

GABLER, M.T.; HEINRICHS, A.J. Dietary protein to metabolizable energy ratios on feed efficiency and structural growth of prepubertal
Holstein heifers. Journal of Dairy Science, v.86, n.1, p. 268-274, $2003 b$

HALL, J.B.; STAIGMILLER, R.B.; BELLOWS, R.A. et al. Body composition and metabolic profiles associated with puberty in beef heifers. Journal of Animal Science, v.73, n.11, p.3409-3420, 1995.

HOFFMAN, P.C.; ESSER, N.M.; BAUMAN, L.M. et al. Short Communication: Effect of Dietary Protein on Growth and Nitrogen Balance of Holstein Heifers. Journal of Dairy Science, v.84, n.4, p.843-847, 2001.

LENG, R.A. Factors affecting the utilization of "poor-quality" forages by ruminants particularly under tropical conditions. Nutrition Research Review, v.3, n.1, p. 277-303, 1990.

LEVENTINI, M.W.; HUNT, C.H.; ROFFLER, R.E. et al. Effect of dietary level of barley-based supplements and ruminal buffer on digestion and growth by beef cattle. Journal of Animal Science, v. 68, n. 12, p.4334-4344, 1990.

LOBLEY, G.E.; CONNELL, A.; LOMAX, M.A. et al. Hepatic detoxification of ammonia in the ovine liver: possible consequences for amino acid catabolism. British Journal of Nutrition, v.73, p.667-685, 1995.

MENDONÇA, S.S.; CAMPOS, J.M.S.; VALADARES FILHO, S.C. et al. Comportamento ingestivo de vacas leiteiras alimentadas com dietas à base de cana-de-açúcar ou silagem de milho. Revista Brasileira de Zootecnia, v.33, n.3, p.723-728, 2004.

MIRANDA, L.F.; QUEIROZ, A.C.; VALADARES FILHO, S.C. et al. Desempenho e desenvolvimento ponderal de novilhas alimentadas com dietas à base de cana-de-açúcar. Revista Brasileira de Zootecnia, v.28, n.3, p.605-613, 1999.

NOCEK, J.E.; RUSSELL, J.B. Protein and energy as an integrated system. Relationship of ruminal protein and carbohydrate availability to microbial synthesis and milk production. Journal of Dairy Science, v.71, n.8, p.2070-2107, 1988.

RUSSELL, J.B.; O'CONNOR, J.D.; FOX, D.G. et al. A net carbohydrate and protein system for evaluation cattle diets. I. Ruminal fermentation. Journal of Animal Science, v.70, n.11, p.3551-3561, 1992.

SANTOS, F.A.P. Metabolismo de proteínas. In: BERCHIELLI, T.T; PIRES, A.V.; OLIVEIRA, S.G. (Org.). Nutrição de ruminantes. Jaboticabal: FUNEP, 2006. p.255-286.

SATTER, S.D.; SLYTER, L.L. Effects of ammonia concentration on rumen microbial protein production "in vitro". British Journal of Nutrition, v.32, n.2, p.245-249, 1974.

SILVA, D.J.; QUEIROZ, A.C. Análise de alimentos: métodos químicos e biológicos. 3.ed. Viçosa, MG: Editora UFV, 2002. 235p.

SILVEIRA, R.N.;BERCHIELLI, T.T.; CANESIN, R.C. et al.Influência do nitrogênio degradável no rúmen sobre a degradabilidade in situ, os parâmetros ruminais e a eficiência de síntese de proteína microbiana em novilhos alimentados com cana-de-açúcar. Revista Brasileira de Zootecnia, v.38, n.3, p.570-579, 2009.

SNIFFEN, C. J.; O'CONNOR, J.D.; VAN SOEST, P.J. et al. A net carbohydrate and protein system for evaluation cattle diets. II. Carbohydrate and protein availability. Journal of Animal Science, v.70, n.11, p.3562-3577, 1992.

TIBO, G.C.; VALADARES FILHO, S.C.; SILVA, J.F.C. et al. Concentrado em dietas de novilhos mestiços F1 Simental x Nelore. 2. Balanço nitrogenado, eficiência microbiana e parâmetros ruminais. Revista Brasileira de Zootecnia, v.29, n.3, p.921-929, 2000.

USHIDA, K.; LASSALAS, B.; JONANY, J.P. Determination of assay parameters for RNA analysis and duodenal samples by spectrophotometry. Influence of sample treatment and preservation. Reproduction Nutrition Development, v.25, n.6, p.1037-1046, 1985.

VAN SOEST, P.J., ROBERTSON, J.B., LEWIS, B.A. Methods for dietary fiber, neutral detergent fiber, and nonstarch polysaccharides in relation to animal nutrition. Journal Dairy Science, v.74, n.10, p.3583-3597, 1991.

ZINN, R.A.; OWENS, F.N. A rapid procedure for purine measurement and its use for estimating net ruminal protein synthesis. Canadian Journal of Animal Science, v.66, n.1, p.157-166, 1986. 